\title{
THE MUSLIMS OF SICILY UNDER CHRISTIAN RULE ${ }^{1}$
}

\author{
Alex MetCALFe \\ Who were the Sicilian Muslims?
}

The Norman invasion of Sicily was neither an invasion, nor was the kingdom that eventually resulted from it particularly 'Norman' in character. At the height of its power in the mid-twelfth century, the kingdom of Sicily included most of the southern Italian peninsula as well as Malta, and colonies along the North African coast. However, it was the island of Sicily that was undoubtedly the gravitational centre of the kingdom's cultural and political life, and its capital of Palermo was probably Europe's wealthiest and most populous city. The island was also home to most of the kingdom's large, Arabicspeaking Muslim communities. Indeed, these formed the majority of the island's population for most of the kingdom's short, but spectacular, existence.

In 1061, almost seventy years before the kingdom was proclaimed, a modest military force under the leadership of Robert Guiscard and Roger of Hauteville, but in the pay of a Sicilian amir Ibn al-Thumna, arrived to assist in a civil war which had already lasted a generation, and had seen the political and administrative disintegration of the island into petty principalities. The advent of these two leaders and those who were to follow them would introduce fundamental and irreversible changes to the demographic, religious and linguistic base of the island over the next 250 years.

In the Islamic period, the view that the Muslims who hailed mainly from Ifrīqiya (roughly the area covered by modern Tunisia) had repopulated the island is matched by an assimilation theory that 'most of its population became Muslim'. ${ }^{2}$ In the ninth and tenth centuries, many towns of strategic importance were indeed

\footnotetext{
${ }^{1}$ This article was originally published in The Society of Norman Italy, ed. Graham A. Loud and Alex Metcalfe (Leiden: Brill, 2002), 289-317.

${ }^{2}$ Yāqūt, $B A S$ (Arabic), 124; translation in Amari BAS, 51. According to Johns (1995), 152, there was 'a scale of acculturation ranging from Greek Christians and Arab Muslims at the two extremes, but with most of the population of the island falling somewhere in the middle'. For general accounts of the Sicilian Muslims in the Norman period, see Amari (1939), Ahmad (1975), Johns (1983), Abulafia (1990) and Maurici (1999).
} 


\section{The Muslims of Sicily under Christian rule}

repopulated after their capture, and appear to have assumed an ArabIslamic character around the entire island. However, change in rural areas seems to have been of a much slower, assimilative type. Even in these more conservative and less carefully monitored environments, most Christian enclaves of Greek or Italo-Greek speakers that had remained are likely to have converted to Islam and/or adopted Arabic as a second language within the space of a few generations. This was probably the scenario in the south-western Val di Mazara, where Arab-Islamic influence had first been established and for most of the Val di Noto in the south-east too. However, it is fair to assume that across and around the many, ragged religious and socio-linguistic frontiers that this created, different communities experienced different degrees of acculturation at varying rates. For example, in 973, Ibn Hawqal, a hostile visitor to Sicily, described how large numbers in rural areas were imperfectly embracing Arab-Islamic norms. In such, communities, he claimed, 'marriage to Christians is [allowed] provided that their male child follows the father by being a bastardised Muslim (mushacmidh), and that a female becomes a Christian like her mother'. ${ }^{3} \mathrm{He}$ also added that they spoke unintelligibly, like 'deaf mutes'. Although the idea that there may have existed degrees of Christianity in Sicily makes for an intriguing, if not entirely unattractive, thesis, it also seems from Ibn Hawqal's description of Palermo that it had barely a remaining trace of Christian culture.

Some evidence suggests remote attempts to strengthen Muslim centres and practices after the fall of Rometta in 965, the last site of Christian resistance. The Fatimid caliph, al- $\mathrm{Mu}^{\mathrm{c}} \mathrm{izz}$ is reported to have ordered the building of mosques, strengthening of fortifications and the urbanisation of the rural population. ${ }^{4}$ However, dispersed settlement patterns from the Norman period, the lack of archaeological evidence for such construction or support from other documentary sources suggests that there may have been some distance between the aim of the order and its implementation.

Nonetheless, it is likely that, by the mid-eleventh century, Sicily was mainly Muslim and almost everyone understood Arabic, particularly in the western Val di Mazara and southern Val di Noto. Only in parts of the north-eastern Val Démone, where Greek and

\footnotetext{
${ }^{3}$ Ibn Hawqal, 129; translation in Kramers and Wiet (1964), 128. Omitted in both versions of Amari's $B A S$.

${ }^{4}$ Al-Nuwayrī, BAS (Arabic), 494-5; translation in Amari, BAS, 179.
} 
Latinate dialects and culture were more concentrated, did Christian communities conspicuously persist. It is these assumptions that underpin and inform the ways in which key social indicators, such as conversion to Christianity, integration and the language question came to change and might be interpreted from the eleventh to thirteenth centuries. Overall, there can be no doubt that the twin processes of repopulation and assimilation that occurred in the two centuries of Islamic rule would come to be reversed, but few could have anticipated the vicissitudes of the better-documented period between 1061 and 1282 .

\section{Changes to the demographic base of the island}

From the time of the circumspect and disjointed Norman-led offensives, the demographic base of the island underwent a series of radical changes that would disrupt and dilute the Muslim communities. According to Ibn al-Athīr, many of the Muslim religious and intellectual elite abandoned the island and, indeed, many were later attested in Spain, Egypt and North Africa. ${ }^{5}$ The same author described how this exodus may have been partially reversed during the North African crop failures of the 1140s when 'many of the wealthier families went to Sicily in search of food, but met with great hardship there'. ${ }^{6}$ Sometimes villeins, or even the population of entire areas, were transplanted from one region to another. Malaterra recorded how Robert Guiscard and Roger I, in 1064 and 1088 respectively, transported the inhabitants of Bugamo and Butera to Calabria. ${ }^{7}$ Twice during Roger II's reign, the population of Djerba, an island off modern Tunisia, was deported to Sicily.

During the early twelfth century, Christian immigrants, many of whom had come from the north of the peninsula, poured into the north-eastern area of the island, the Val Démone, which was closest to the Italian mainland. Of particular note were the 'Lombard' communities, whose influence would come to dominate the towns of Novara, S. Fratello, Nicosia, Sperlinga, Aidone and Piazza Armerina,

\footnotetext{
${ }^{5}$ Ibn al-Athīr, $B A S$ (Arabic), 319; translation in Amari, BAS, 114.

${ }^{6}$ Ibn al-Athīr, BAS (Arabic), 332; translation in Amari, BAS, 119. A royal Sicilian register of men from 1141 hints that, on arrival, they may have been assigned the status of landless 'villeins', Seville, ADM, no. 1119.

${ }^{7}$ Malaterra, II.36, p. 47 and IV.12, p. 92.
} 
thus forming something of a barrier across the island. ${ }^{8}$ Attempts to manage the displaced communities were hampered by a sustained, but poorly documented, baronial revolt after the death of Roger I. ${ }^{9}$ Indeed, given the Muslim depopulation and Christian repopulation of the Val Démone, and the increasingly overt animosity between the 'Lombard' and Muslim communities, it is likely that the majority of Muslims were living well to the west of this belt by the second half of the twelfth century. For the year 1161, Falcandus noted that, 'to the present day, they [the Muslims] hate the North Italian people so much that they have refused to live in that part of Sicily again, but even avoid going there at all'. ${ }^{10}$ The dramatic effects of demographic change are illustrated by the example of the north-eastern port of Messina. When the town was besieged by Roger in 1061, it is quite evident that there was a significant Muslim population. ${ }^{11}$ But Ibn Jubayr's eye-witness description of it in 1184 tells of a city in which 'no Muslims have settled' and which was 'crammed with worshipers of crosses [i.e. Christians] ${ }^{12}$ In contrast to Messina in the north-east, were the towns of the south-west such as Africa-facing Agrigento in which few Christians had settled until at least $1189{ }^{13}$

In spite of the changing environment, Muslims continued to play an important role in the socio-economic life of the island as merchants, craftsmen and farmers. Most of the Muslim population had settled in the west of the island where wheat had been grown since classical times. Economically, wheat was the most important crop of the entire kingdom, and its export to North Africa in return for gold was vital to both parties and explains much of Sicily's expansionist policies and actions towards the North African cities. However, the wider picture was one of transition as Sicily's longer distance trade slowly withered and the lucrative new commercial routes between Europe and the southern Mediterranean fell increasingly into the hands of Genoese, Pisan and Venetian merchants who had been quick to establish commercial bases in both

\footnotetext{
${ }^{8}$ Bresc (1985), 256.

${ }^{9}$ During the troubles, the settlement of Focerò was destroyed three times. The revolt is also mentioned in a dispute over rights in 1123, Cusa, Diplomi, 471-2.

${ }^{10}$ Falcandus, 70; translation in Tyrants, 122.

${ }^{11}$ Malaterra, II.4-11, pp. 87-92.

${ }^{12}$ Ibn Jubayr 296; translation in Broadhurst (1952), 338.

${ }^{13}$ Le più antiche carte dell'archivio di Agrigento (1092-1282), ed. P. Collura (Palermo 1960), 307.
} 


\section{Alex Metcalfe}

Palermo and Messina. ${ }^{14}$ In general, the main demographic divisions that had existed during the Islamic period continued, but saw an increasing degree of polarisation between the settlement of the east and west of the island. So while the grain-growing, south-western Val di Mazara remained the zone of most dense Muslim settlement, Latin colonists entered through the Val Démone and the main Italianfacing ports from which they spread west. Although a good deal of variation and contrast remained at local levels, the overall effect of migration and repopulation were highly significant factors in shaping the island's social composition between 1060 and 1250 .

\section{Alliances and early Muslim-Christian relations}

Even before the invasion, Islamic Sicily had been politically fragmented and twenty-five years of civil strife had failed to result in the ascendancy if any one particular party. The Christian knights, in spite of being numerically disadvantaged, held the balance of power through their military capability and their willingness to make ad hoc alliances with complicit Muslim factions on the island. Thus, the early use of Muslim soldiers and the inclusion of members of the Muslim elite in the political decision-making process generally, can be seen as a practical response to the problem of attaining and maintaining control. Not surprisingly, there was a great deal of ambivalence and uncertainty over the relationship between the Christian leaders and their subject peoples from the outset. Alliances with leading Sicilian Muslims, such as that with the amir Ibn alThumna, strongly suggest that the early invaders could not have had an overtly religious agenda when they first entered the island, in spite of claims to the contrary by early Latin historical writers. In such authors an accurate portrayal of events was tinted with invective directed against the soft target of an infidel and alien enemy. Thus, for William of Apulia, Palermo of the late eleventh century was a city 'hostile to God' and 'enslaved by demons'. ${ }^{15}$ Malaterra described how Count Roger ordered churches to be built throughout

\footnotetext{
${ }^{14}$ Abulafia (1977), especially 90-8, 182-3, 263-4 and Abulafia (1986).

${ }^{15}$ William of Apulia, book III, lines 286-7, p. 178. These sentiments were attributed to Robert Guiscard in a rhetorical speech.
} 
Sicily, while Pope Gregory VII had encouraged Roger by letter 'to forward the cult of the Christian name among the pagans'. ${ }^{16}$

The fact that Sicily was largely Muslim may have provided all the more excuse for an invasion, but it makes an unconvincing reason for action per se given the zeal with which Robert and Roger had already annexed Christian territories on the southern Italian mainland. Nonetheless, some notable Muslims did convert to Christianity, but even with explicit accounts, it is difficult to know the extent to which such conduct spearheaded wider social change. Equally unknown is whether leading Muslims converted because they were required to, or whether they were also happy to benefit from the material gains that conversion offered. These could be considerable. A donation in Greek records how 'Roger, who was once called Ahmad in the religion of the Hagarenes [Muslims]' gave three estates to the archbishop-elect of the church of Palermo. These had been conceded to Roger/Ahmad by his godfather, Count Roger II. ${ }^{17}$ If the connection between conversion and material reward is not absolutely explicit here, there were other cases in which it was. At the capture of Castrogiovanni (modern Enna) in 1087, Malaterra relates how a certain 'Chamut' converted and moved to Calabria where he received lands. ${ }^{18}$ Even if the attested conversion of some Muslim community leaders was unusual, their acceptance of material rewards set an important precedent and showed the potential for wider conversion without the direct involvement of the Church, nor with any great effort on behalf of the ruling elite. Yet, there remains no evidence to support a policy of widespread conversion in the early conquest period. To the contrary, Malaterra noted that Muslims were not only to keep their faith, but also their culture after the capture of Palermo in 1072, although the principal mosque was converted to become the new cathedral. ${ }^{19}$ In exceptional cases, conversion seems to have been actively discouraged. Muslim troops were used from as

\footnotetext{
${ }^{16}$ Malaterra, IV.7, p. 89. Gregory VII, Registrum, III.11, p. 272, a letter sent to Archbishop Arnold of Acerenza for onward transmission to Count Roger.

${ }^{17}$ Cusa, Diplomi, 16.

${ }^{18}$ Malaterra, IV.6, p. 88. 'Chamut' is derived from the common Arabic name Hammūd. However, the suggestion that he was from the Hammūdid tribe and may be related to others bearing the same name, such as Abū l-Qāsim bin Hammūd, is pure speculation. For the perpetuation of this idea, see Bresc (1974), 267-304, Rizzitano (1977), 205-7 and Amara and Nef (2001), 121-7.

${ }^{19}$ Malaterra, II.45, p. 53 and Amatus, VI.19, pp. 281-2.
} 


\section{Alex Metcalfe}

early as the capture of Salerno in $1076 .{ }^{20}$ According to Eadmer's 'Life of Saint Anselm', many Muslim soldiers serving under Count Roger would have converted had they not dreaded Roger's harshness towards them in reprisal. ${ }^{21}$ Certainly, Muslim soldiers provided an uncompromising force against insurgent Christian towns on the mainland, above all in the 1120s and 1130s, and Muslim contingents were used in the army until the end of the thirteenth century.

\section{Indirect rule: the fiscal, legal and religious status of Muslims}

By the mid-1090s, the Sicilian Muslims had succumbed to life under 'infidel' Christian rule relatively peaceably. Large numbers had fought alongside the Christians and had facilitated the conquest of their own island while the peasants who made up the majority of the population now found themselves with the defined rights and responsibilities of villeins allotted to landlords. Terms of service for Muslim villeins were not necessarily worse than for the other communities, although some landlords were keener to attract Latin settlers than others. ${ }^{22}$ A proliferation of 'feudal' terms, many synonymous, were used across the island's three administrative languages to describe classes of villeins. References are scattered among only a few registers and suggest that a broad distinction was made between services villeins owed on their persons and on conditions of their tenure, although classifications were subject to change, finer sub-divisions and degrees of local variation. ${ }^{23}$ It was in the interests of both landlords and, later, also of the royal fiscal administration to limit the movements of the existing villein population, attempt to retrieve fugitives and register newly-weds while attracting newcomers onto the land and therefore into taxable categories.

The legal status of Sicilian Muslims is slightly less obscure than their fiscal status, with evidence pointing to the use of Islamic $\operatorname{Shari}^{c} a$ law to decide matters of custom or civil dispute that arose

\footnotetext{
${ }^{20}$ Amatus, VIII.14, p. 354

${ }^{21}$ The Life of Saint Anselm, Archbishop of Canterbury, by Eadmer, ed. and trans. R.W. Southern (London 1962), ii, 23, pp. 110-12.

${ }^{22}$ The constitution of Patti decreed that only 'men of the Latin tongue, whoever they might be' could settle in the town itself. Roger II Diplomata, pp. 64-6, no. 23. To landlords generally, Muslims on their land were valued as taxable commodities because they paid the jizya. See below.

${ }^{23}$ See Johns, The Royal Diwan (forthcoming).
} 


\section{The Muslims of Sicily under Christian rule}

within Muslim communities. ${ }^{24}$ Even in cases between Muslims and non-Muslims, swearing on the Qur ${ }^{\circ} \bar{n}$ and the use of Islamic law was still respected. ${ }^{25}$ As in orthodox Sunn̄̄ Ifrīqiya, Sicilian Muslim jurists predominantly adhered to the Mālikī school of Islamic law. Indeed, the earliest Muslim force to invade Sicily had been under the command of the leading Mālikī authority, Asad bin al-Furāt. A number of eminent Mālikī jurists of Sicilian origin are also later attested, including the imām al-Māzarī (d. 1141) whose influential religious opinions argued that judgements pronounced by Muslim magistrates appointed by 'infidels' in Christian Sicily had legal force and should be obeyed conditionally. ${ }^{26}$ This was consistent with the typically Mālikî view that even bad government was better than no government, in contrast to the more militant philosophy of the Almoravids and Almohads that was spreading across North Africa. Thus, Muslim qadi-s (magistrates), attested in Sicily throughout the twelfth century, retained both social status and legal authority within their own religious communities. ${ }^{27}$ In return for security (dhimma) for their property and legal protection for themselves, the tax required from Muslims and Jews was slightly higher than Christians, as non-Christian communities probably paid the jizya, a type of religious poll tax based on an Islamic precedent. ${ }^{28}$ Hence, an important connection can be made between Sicilian fiscal structures and the Muslims' legal standing that defined their place within a society otherwise divided along religious lines.

The emerging picture is of an Islamic community that continued to function relatively normally, sheltering under a type of indirect rule, its judicial and religious status theoretically guaranteed in return for a

\footnotetext{
${ }^{24}$ In 1168, Latins, Greeks, Jews and Muslims were said to be judged unusquisque iuxta suam legem, see Catana Sacra, 89.

${ }^{25}$ References to the use of Islamic law occur in two Palermitan house sale agreements drafted in Arabic from 1190 and 1196, Cusa, Diplomi, pp. 44-6 and 499-501. In the latter case, the deal was struck between Muslim and Christian parties. Around 1177, the three Muslims villeins took a pledge on the Quran in the presence of their landlord, Donatus, abbot of Saint John of the Hermits in Palermo, that they would 'neither disdain nor desert their lord, nor would they ever dissent from the church's obedience', Cusa, Diplomi, 111-12.

${ }^{26}$ Brett (1995), especially 330-3

${ }^{27}$ Cusa, Diplomi, 471 (1123), 69 (1143), 475 (1145) and 273 (1183).

28 'Fight those who do not believe [ ... ] until they pay the jizya', Qur`ān ix, 29. Generally, see Cahen (1965), 227-31, 559-62, and specifically Johns, The Royal Diwan (forthcoming).
} 
higher tax burden and a reversal of its former prestigious social position. For many of Sicily's Muslims, daily life under Christian rule thus continued without substantial change, above all in the Val di Mazara where their numbers were far greater and 'Latin' settlement was limited. Even in the mid-1180s, the Spanish Muslim pilgrim, Ibn Jubayr marvelled at the local Christians' tolerance of a noisy religious procession in Trapani. ${ }^{29}$

Whether such conspicuous behaviour or the full range of religious practices could have been pursued much outside the Val di Mazara is rather more debatable. Even within it, many estates among the network of Muslim settlements were so tiny that they could not have supported much of a socio-religious infrastructure. Although Ibn Jubayr noted the sound of the muezzin giving the call to prayer a short distance from Palermo, he also mentioned that it had been a long time since he had heard it, ${ }^{30} \mathrm{He}$ had, however, already passed through three large urban centres, namely Messina, Cefalù and Termini, in the previous week. On reaching Palermo in the middle of Ramadan, we learn that the Muslims there had preserved only a 'trace' of their faith, about which he proceeds to inform his anxious Muslim readers. He reports that they maintained their mosques and again noticed the prayer call which was also answered by the prayers of the faithful, but failed to mention that any of them were observing the fast during the holy month-one of the five defining 'pillars' of Islam. He also noted the existence of countless small mosques and a single congregational mosque $\left(j \bar{a} m i^{c}\right)$ in which the Friday sermon had been banned, presumably to avoid the propagation of any politico-religious polemic that might have been given. This appears to have undermined the point of the main weekly prayers to the, extent that consequently they were not even held there. ${ }^{31}$

But in whatever ways religious practice mayor may not have been restricted or carried out locally, there can be no doubt that the creation of fiscal and legal divisions according to religion and the degree of autonomy that indirect rule thus afforded, contributed to the preservation of a Muslim consciousness, identity and sense of community throughout the Norman period.

\footnotetext{
${ }^{29} \mathrm{Ibn}$ Jubayr, 310; translation in Broadhurst (1952), 353.

${ }^{30}$ Ibid., 303; and ibid., 346

${ }^{31}$ Ibid., 305; and ibid., 348.
} 
The influence of Arab-Islamic traditions and Muslim administrators

Religious conversion of the Muslim elite may have been the Sicilian kings' preferred option, but it was certainly not a pre-requisite for political power. This is shown most obviously by the figure of Abū lQāsim, the Muslim leader who played a vital role in the island's administration, commerce and politics under William I and II. In the much earlier and skeletal pre-regnum administration, c. 1108-c. 1129, at least some of the key figures were Muslims and included the poet and administrator Abu $1-$ Daw $^{\circ}$ who had well-placed connections with the Ifriqiyan Zirids. ${ }^{32}$ This important but little-known figure later wrote an elegy on the death of Roger II's eldest son in 1148 and his family associations in Sicily suggest that they remained close to sources of power until at least the $1160 \mathrm{~s}^{33}$

Other distinguished personnel in this period included the amir Christodoulos and amir of amirs, George of Antioch. The former was frequently mentioned in Greek and Latin documents until 1125 and can be identified with 'Abd al-Raḥmān 'the Christian' mentioned in Arabic sources. ${ }^{34}$ On the other hand, the trilingual and highly experienced George had worked for the Byzantine emperor and then for the Zirid dynasty in Ifriqiya as a senior financial advisor before arriving in Sicily. His biography, given by the historian alMaqrizl, leaves us in no doubt that he was central to the establishment of the Sicilian kingdom, the reformation of the fiscal administration and the presentation of Roger II as a ruler in the Islamic style. ${ }^{35}$ Although very little is known of this early formative period, it is clear that a mix of Christians and Muslims were instrumental in the embryonic administration of the pre-regnum period as they continued to be in the second half of the twelfth century too. However, as we shall see, influences both from within and outside Sicily would soon tip the delicate political balance established under George of Antioch after his death in 1151 and after that of King Roger II in 1154.

\footnotetext{
${ }^{32}$ For the poetry of Abū 1-Daw ${ }^{\circ}$ and his correspondence with Abū 1-Ṣalt at the Zirid court, see De Simone (1999), 3-15.

${ }^{33}$ Cusa, Diplomi, 61-6, 101-6 and 471-2.

${ }^{34}$ Ménager (1960), 28-30.

${ }^{35}$ Al-Maqrīzì, III. $18-20$.
} 


\section{Alex Metcalfe}

\section{Arab-Muslim cultural life around the royal palaces}

Prior to the building of the first palaces around 1130, it is difficult to speak of a 'capital', nor of any central or well-organised administration, nor of the existence of a 'court'. Even after the creation of the kingdom and construction of the royal palaces, it would be easy to overstate the extent and permanency of any 'court culture' or a 'court entourage'. Nor, for that matter, is there any evidence that the specific institution of a harem was included within the palaces, although this is sometimes mentioned in the same breath as 'pleasure palaces' and 'palace eunuchs' which, taken together, may conjure up exotic, but misplaced, images of Orientalist odalisques from Ottoman Turkey. We shall, however, consider the fundamental importance of the 'palace eunuchs' to the management and stability of the kingdom later. Confusion can also be created by the liberal use of misnomers such as 'Arabs' when actually referring to Muslims, ex-Muslims or Arabic-speakers of Christian, Jewish or Muslim backgrounds and similar caveats accompany discussions of 'Greeks' or 'Greek culture' both outside and within the palaces. The latter, for instance, ranged enormously from the translation of ancient Greek texts, to the influence of senior officials who knew Greek, to the importance of Greek as an administrative language as well as to the appropriation of Byzantine decorative styles and sporadic royal patronage of the Eastern Church. Certainly, links between Palermo and Byzantine and Islamic regions were far less remote than those between the so-called 'Norman kings' and Normandy, and indeed the Sicilian kings drew little inspiration from the chill poverty of northern Europe, but rather focussed eastwards to Cairo and Constantinople and south towards Ifrīqiya. Even so, many modern authors still prefer to follow the northern Latin sources in referring to the Sicilian kings 'as 'the Normans'. Indeed, phrases such as 'the Norman conquest' or 'the Norman kingdom' beg uneven comparisons with contemporary England and northern France and run the risk of transmitting a rash of preconceived ideas about the character, dynamics and development of authority on the island.

Much too has been made of cross-cultural academic activities that took place around the palaces during the Norman period. Some administrators of the second half of the twelfth century, such as Maio, Aristippus and Eugenius, were indeed closely involved in the transmission of ancient philosophical, scientific and literary texts, especially Greek, but also Arabic, into Latin. The royal patronage of 


\section{The Muslims of Sicily under Christian rule}

Muslim and Byzantine scholars, at its brief height under Roger II, is often seen as a part of the same high-brow cultural package. However, commissioned original works that have come to be considered important, such as the geographer al-Idrīsis's 'Book of Roger' and Nilos Doxapatris' political thesis, 'The History of the Five Patriarchates', were exceptional. Neither author was native to the island, nor were these works ever translated into Latin, perhaps because they were thought to contain only contemporary opinions about, lower prestige material. Otherwise, original literary output that has come to be associated with the Palermo 'court circle' tends to be the product of a varied social elite who wrote for pleasure or were merely passing through the kingdom at the time and were not always in need of patronage.

In other respects, native Sicilian Muslim intellectual activity never recovered from its sudden collapse caused directly by the emigration of their social elite at the start of the Norman period. So while the Sicilian grammarian Ibn al-Qatțā $\bar{a}^{\mathrm{c}}$ could give details of 170 Sicilian authors writing in Arabic from the Islamic period, only a handful are known from the twelfth century. He had prudently left the island for safer employment in Egypt where he became tutor to Ibn Barrī and the sons of the Fatimid wazìr al-Afḍal bin Badr al-Jamālīi. ${ }^{36}$

\section{The Muslims and the Sicilian kings}

After the unification of the kingdom and its formal establishment in 1130 with the coronation of Roger II, there followed almost two decades of piecemeal administrative reform and conscious modelling of the kingship. The ruling apparatus of the Sicilian kings was characterised by administrative and artistic elements poached from sources with origins that lay outside the kingdom. For example, many of the structures and practices of the fiscal administration are comparable to, and post-date, those used in Fatimid Egypt. Specifically, the format, calligraphic dīwānī script, royal titles and the 'alama or 'insignia/signatures' that appeared on all post-1133 royal Arabic diplomata appear to be based on contemporary

\footnotetext{
${ }^{36}$ The former was a grammar specialist who worked in the Fatimid Diusin alInshii' and is thought to have died in Cairo in 1121. The latter, who effectively controlled Egypt, was instrumental in the establishment of the Dīwān al-Tăhqīq in $1107-8$.
} 


\section{Alex Metcalfe}

Egyptian models. ${ }^{37}$ More importantly, the administrative office known as the Dīwān al-Tahqīq al-Macmūr, which was founded by 1149 and responsible for the compiling, issuing, inspecting and updating of fiscal registers of lands and men in Sicily and Calabria, appears to have been based on the Fatimid Dìwān al-Tahqīq, itself founded in $1107 .{ }^{38}$ The other main financial office was that of the Dīwān al-Mac mūr, which was operational by 1145 and responsible for the general management of the royal demesne in Sicily and Calabria, including the collection of revenues from crown property. These two financial offices, in which Arabic was the basic working language, drove much of the kingdom's economy and Muslim or exMuslim staff were instrumental in the running of both. In addition, there is reason to believe that the adoption of certain royal regalia and much of the kings' highly developed ceremonial protocol also had southern Mediterranean origins as opposed to being a rediscovered inheritance from the Muslim Kalbid dynasty of Sicily, which had disintegrated during the first half of the eleventh century.

There is no doubt that the Sicilian kings were at pains to give the impression of legitimate authority in every direction both within and outside the kingdom and spared no expense on the trappings of power required to do so. Yet the relevance of Arab-Islamic influence in the royal household and administration remains highly debatable. For example, it is not clear whether the conspicuous borrowings from three cultural traditions and use of three administrative languages (Latin, Greek and Arabic) formed part of an elaborate royal motif designed to emphasise Sicily's tripartite nature. A classical allusion to the 'three-tongued Sicilians' by the poet Peter of Eboli and his references to Sicily by its ancient name of Trinacria, or 'three-cornered', a usage which also occurs in the 'Letter to Peter' attributed to Hugo Falcandus and in the letters of Peter of Blois, show how such ideas were in wider circulation by at least the latter third of the twelfth century. ${ }^{39}$ Under Roger II, trilingual inscriptions

\footnotetext{
${ }^{37}$ Johns (1993), 133-59.

${ }^{38}$ For the general context and development of Arab-Islamic chanceries, see Colin, Duri and Gottschalk (1962), and, specifically, see Johns The Royal Diwan (forthcoming).

${ }^{39}$ The Siculi trilingues of Apuleius Metamorphoses 11.5 in the 2nd century AD. Cf. also Peter of Eboli, Liber ad Honorem Augusti, ed. G. B. Siragusa (FSI 1906), p. 9, line 56, 'hactenus urbs felix populo dotata trilingui'. Trinacria, ibid. pp. 74, 84, 89, lines 1059, 1079, 1273; the 'Letter to Peter' in Falcandus, 172 (translation, Tyrants, 254) and Peter of Blois, Epistola no. 46, MPL ccvii.133-4
} 
and an awkward confluence of Arab-Islamic, Byzantine and Romanesque architectural and decorative styles in the royal chapel and palaces has been understood as an attempt to reconcile the recent unification of the realm with the reality of a society divided by religion, language, politics and culture. ${ }^{40}$ Such syncretic interpretations may also have contributed to confusion with the modern notion of religious tolerance. ${ }^{41}$ What is clear is that the purposeful adoption of many of these cosmetic and imported accoutrements has clouded our understanding of the relationship between the kingdom's conquered Islamic communities and a kingship that owed so much to Arab-Islamic traditions and relied so heavily on the employment of Muslim or ex-Muslim administrators. Indeed, one might query whether a kingship as self-conscious as that set up by George of Antioch for Roger II and which apparently proclaimed the ideal of linguistic, artistic and cultural diversity within the setting of a harmonious Christian kingdom could ever have been compatible with a society that had also been carefully divided up along religious lines. Propaganda, experiment or otherwise, the theory behind the kingship and the practicalities of its rule did not always add up, for while some aspects emphasised the kingdom's unity, others betrayed its opposing diversities.

\section{The presentation of Muslim-Christian relations}

Evidence for this is provided by the Sicilian kings' description of themselves in epithets and formulae that consistently maintained a pro-Christian stance and never presented Muslim-Christian relations as anything but adversarial dogmas. In this respect at least, they echoed the sentiments of the early Latin historiographers. Count Roger I's wife and regent, Adelaide, was described in Arabic in 1109 as 'the defender of the Christian faith'. ${ }^{42}$ In 1117, as a young Count, Roger II was described as 'agent of the Christians and slave of Jesus Christ' ${ }^{43}$ and from an early stage, Greek chancery signatures

\footnotetext{
${ }^{40}$ For the views of art historians, see Demus (1950), Kitzinger (1960), Borsook (1990) and Tronzo (1997). For the royal trilingual inscriptions, see Arnari (1971), 29-38 and 198-214. For specifically Arab-Islamic influences in the palaces, see ]ohns (1993).

${ }^{41}$ For the persistence of such ideas, see Douglas (1976), Marongiu (1963), 30720, and for discussion see also the chapter by Hubert Houben, pp. 319-39.

${ }^{42}$ Cusa, Diplomi, 403.

${ }^{43}$ Cusa, Diplomi, 385.
} 


\section{Alex Metcalfe}

described him as, 'in Christ the Lord a holy, mighty King and helper of the Christians'. ${ }^{44}$ A royal mantle made in 1133/4 even depicted lions attacking camels (i.e. Christians attacking Muslims). Some royal epithets were borrowed from the Arab-Islamic tradition, but had any overtly Islamic elements stripped out of them in line with an eclectic, resourceful and even slightly pagan kingship that only operated publicly under a Christian banner. ${ }^{45}$ This calculated ideology simultaneously presented the kings as heirs to an ArabIslamic inheritance while introducing themselves as the champions of Christianity and by the 1140s, such formulae had become standard royal epithets as had the confident and emphatic association of Christ, authority and ascendancy. Arabic chancery sources began to celebrate the king's royal orders as officially 'strengthened by God, supported by His power and victorious by His force'. ${ }^{46}$ William II was considered as the 'defender of the pope at Rome' and 'protector of the Christian faith'. ${ }^{47}$ Some of the formulae in question were imported and adapted from contemporary Islamic chanceries and only appeared in their unabridged forms in Arabic, thereby revealing at least one direction in which the propaganda was aimed. However, the view that the appropriation of southern Mediterranean cultural trappings and any perceived ideological accommodation in the art, administration, palaces, manners and protocols of the Sicilian kings may be interpreted as pro-Muslim or reconcilable with royal policies towards the Muslims (inasmuch as any tangible 'policies' can be detected at all), should be treated with caution as, indeed, should any attempt to coordinate the art history of the kingdom with its actual history.

The 'palace Saracens' and religious ambiguity

A distinctive feature of the Sicilian kingship was the employment of Muslims or converted ex-Muslims. In Latin sources these were col-

\footnotetext{
${ }^{44}$ For example, Cusa, Diplomi, 129.

${ }^{45}$ The Muslim shahāda or testimony of faith was removed from Sicilian coinage at an early stage, see Johns (1986), 11-54, although Arabic inscriptions from inside one of the royal palaces contain references to a ritual performed by Muslim pilgrims in Mecca.

${ }^{46}$ E.g. Cusa, Diplomi, 134.

${ }^{47}$ E.g. Cusa, Diplomi, 245.
} 


\section{The Muslims of Sicily under Christian rule}

lectively known as the 'palace Saracens' ${ }^{48}$ These functionaries performed a variety of tasks and are attested from the early 1130s until the end of the Norman period. Most were ancillary staff around the palaces, but some were hand-picked and highly trained for managing the administration and were also groomed for military command. A great deal of mystery still surrounds these characters but all seem to have been eunuchs who had been converted to Christianity. Most of the higher ranking ones adopted Latin or Frankish baptismal names by which they were usually referred, preceded by the honorific Arabic title of $q \bar{a}^{3} i d$ or 'leader'. Thus, among others helping to run the royal chancery, we find the $q \bar{a}^{\supset} i d$ s Philip, Martin, Peter and Richard - all castrated ex-Muslims, They were probably drawn from the Sicilian colonies in Ifrīqiya, perhaps in particular from the maverick island of Djerba, and their employment mirrored the practices of contemporary Arab-Islamic chanceries, although eunuchs were also used by the Byzantines. ${ }^{49}$ After mid-1148, provision had even been made for all the palace staff to be buried in a Benedictine monastery between the royal palace and the church of Saint George of Kemonia. ${ }^{50}$

It was an open secret that most of the 'palace Saracens' continued to practise Islam. A later marginal note in Romuald's Chronicon which referred to Philip of Mahdiyya, a eunuch under Roger Il, commented that 'he appeared to be Christian, but in mind and deed he was completely Muslim', a sentiment echoed by contemporary Muslim sources. ${ }^{51}$ 'Falcandus' remarked that $q \bar{a}^{\supset} i d$ Peter, a eunuch of the 1160s, 'was Christian in appearance and name only, but in spirit was Muslim just like all the palace eunuchs. ${ }^{52}$ In the $1180 \mathrm{~s}$, Ibn Jubayr recalled an informant's report that many palace staff, including some of William II's ministers, were covertly Muslim. ${ }^{53}$ By and large, this state of affairs was allowed to continue with complicity at the highest level.

\footnotetext{
${ }^{48}$ Falcandus refers to them generically as either eunuchi, or sometimes saraceni palatii, e.g Falcandus, 45, 56, 115-17, 119 (translation, Tyrants, 99, 109, 166-7, 170).

${ }^{49}$ For eunuchs in medieval Islam generally, see Ayalon (1999).

${ }^{50}$ Roger II Diplomata, pp. 217-23, no. 76.

${ }^{51}$ Romuald, 235. Ibn al-Athīr commented similarly about Philip and his servants, see BAS (Arabic), 338; translation in Amari, BAS, 122.

${ }^{52}$ Falcandus, 25; translation in Tyrants, 78.

${ }^{53}$ Ibn Jubayr, 297; translation in Broadhurst (1952), 340.
} 


\section{Alex Metcalfe}

Not only were the 'palace Saracens' and the island's leading Muslims politically active within the palaces, but they also articulated the views of their co-religionists with whom most apparently identified and some even maintained communication with overseas contacts. ${ }^{54}$ Predictably, their politically precarious jobs frequently left them open to accusations of treachery. Fa1candus claimed there was a particularly close relationship between Queen Margaret and the powerful $q \bar{a}^{\curvearrowright}$ id Peter who eventually fled to the Almohads in 1167. The same source alleged political co-operation between the 'palace Saracens' and the Almohads over the loss of Sicilian territories in Ifrīqiya ${ }^{55} \mathrm{He}$ also claimed that the general massacre of 'palace Saracens' and Muslims in Palermo in 1161 was avenged by the eunuch $q \bar{a}^{\supset} i d$ Martin who put many Christians on trial while William I was on the mainland putting down the rebels. ${ }^{56}$

\section{Did Roger II resort to a conversion policy?}

Two early thirteenth-century accounts, one in Arabic and the other in Latin, record the trial and execution of Roger II's favoured 'palace Saracen' called Philip, along with his 'accomplices and associates' in late 1153 during the Muslim holy month of Ramadan. ${ }^{57}$ Although these sources disagree about the reasons behind Philip's arrest, neither doubts that it involved a religious matter. However, it is difficult to tease apart the political and religious motives of this affair from its political and religious consequences. The suppression of 'palace Saracens', on whose administrative skills the new king William would be heavily dependent, came during the politically sensitive succession period and only three months before Roger Il's death at the end of February 1154. At Easter in 1151, Roger's politically inexperienced son had been installed as joint-ruler following the premature deaths of the king's other four sons. ${ }^{58}$ Around the same

${ }^{54}$ Al-Harawī (d. 1215) recorded that in 1175 Sicily's leading Muslim, Abū 1Qāsim, personally gave him a letter addressed to Saladin urging him to invade Sicily, see BAS (Arabic), 79; translation in Amari BAS, appendix, 2. In 1185, Abū 1-Qāsim was accused of communications with the Almohads. Ibn Jubayr, 314; translation in Broadhurst (1952), 358.

${ }^{55}$ Falcandus, 27, 96-9; translation in Tyrants, 80, 144-7.

${ }^{56}$ Falcandus, 56; translation in Tyrants, 129-30.

${ }^{57} \mathrm{Ibn}$ al-Athīr, BAS (Arabic), 338; translation in Amari, BAS, 122 and a lengthy marginal note in Romuald, 234.

${ }^{58}$ Tancred died c. 1138; Anfusus in October 1144; Henry c. 1145, and Roger in May 1149, see Houben (1999), 124-5. 


\section{The Muslims of Sicily under Christian rule}

time, the new chancery head, Maio of Bari, can be seen to have been exercising an unprecedented degree of independence within the fiscal administration, following the death of George of Antioch in 1151. ${ }^{59}$ Furthermore, Romuald recorded how, towards the end of his life,

Roger had given up secular affairs and worked in every way to convert Muslims and Jews whom he richly rewarded with gifts. ${ }^{60}$ So, if Roger had withdrawn from political life, then the most likely dates for his retirement strongly converge on the years 1152-3.

If these observations are combined with Ibn al-Athir's remark that Philip's death was 'the first blow dealt to the Muslims', then the incident might also be regarded as a turning-point in wider MuslimChristian relations. However, the chief objection to the adoption of a conversion policy is the lack of evidence from this period that relates to converts who, according to Romuald, had been so richly bestowed with gifts. Indeed, the idea that a king should die piously could also be read as a religious and literary topos. ${ }^{61}$ Even so, the purge of 'palace Saracens' at the end of Roger I1's reign served as a reminder to all the Sicilian Muslims of their political debility. At the same time, this act strengthened the increasingly powerful hand of 'Latin' forces around the new king who had been quick to learn that to attack the 'palace Saracens' was indirectly to undermine the kingship itself. Indeed, from the early 1160s, the Latin nobility and bishops, in the form of the familiares regis, interposed themselves between the king and his 'palace Saracens'. ${ }^{62}$ So although Philip's death may not have been part of a wider conversion policy, it marked an early stage in the longer-term political development of the island that would ultimately and fundamentally affect all its Muslims. As we have seen, testimony from 'Falcandus' and Ibn Jubayr shows that, from the time of Philip's death, the 'palace Saracens' remained politically vulnerable. Yet, in spite of changing circumstances, reliance on their administrative skills allowed their openly equivocal religious position to continue. As such, any apparent lack of clear royal policy can be understood as less irresolute than deliberately relaxed.

The relevance of the 'palace Saracens' extends further than merely palace politics or as examples of conversion because their behaviour

\footnotetext{
${ }^{59}$ Johns and Metcalfe (1999), 235.

${ }^{60}$ Romuald, 235; translation in Tyrants, 220.

${ }^{61}$ Matthew (1981), 268.

${ }^{62}$ One might especially note the denunciation of $q \bar{a}^{3} i d$ Peter by Queen Margaret's cousin Count Gilbert of Gravina, 'it had been a lunatic idea that one should raise up a Muslim slave', Falcandus, 101; English translation, Tyrants, 148.
} 


\section{Alex Metcalfe}

had helped to make religious ambivalence an acceptable if compromised response to the problem of living under infidel Christian rule. Such an admissible dissimulation of faith under duress is the principle known to Islamic jurists as taqiyya. ${ }^{63}$ The long-standing royal policy of ambiguity and qualified forbearance towards them as only nominally Christian permitted the emergence of a conspicuous group with a dubious religious status that hovered somewhere between Christian and Muslim. And for those prepared to run this risk or happy to subordinate their religious beliefs to their career prospects, there was much to be gained by conversion, nominal or otherwise.

\section{The case of Ibn Zurca and mosque conversions}

In the 1180s, Ibn Jubayr recalled how a certain jurist called Ibn Zurc ${ }^{\mathrm{c}} \mathrm{a}$ was persuaded to convert by 'officials' (al- $\left.{ }^{c} u m m \bar{a} l\right)$, after which he was to give opinions, perhaps exceptionally, in legal cases for both Muslims and Christians. ${ }^{64}$ Of particular note in this case is that Ibn Zurca owned a mosque opposite his house that he subsequently converted to a church. Presumably Ibn Zur ${ }^{c}$ a's church, which need not have been a grand structure, still resembled a mosque, but no mention is made of its former congregation or those it now attracted. Nor was this the only religious building in Sicily that had undergone such a modification. As early as 973, Ibn Hawqal recorded how the great congregational mosque in Palermo had once been a Greek church. ${ }^{65}$ William of Apulia then tells us that exactly a century later, Robert Guiscard converted the main mosque to a cathedral church devoted to the Virgin Mother - 'where there was once the seat of Muhammad and his demons, he set the throne of God' ${ }^{66}$ Among Arabic sources, Ibn Hamdīs poetically recalled that in the late eleventh century the Christians had 'changed mosques into churches' ${ }^{67}$ This process continued into the twelfth century with the conversion of a mosque into a church dedicated to Thomas Becket by Bishop Robert of Catania in $1179 .{ }^{68}$ However, if these mosques became churches, there were many more that must have remained as

\footnotetext{
${ }^{63}$ Generally, see Strothmann and Djebli (2000), 134-6.

${ }^{64}$ Ibn Jubayr, 313; translation in Broadhurst (1952), 357.

${ }^{65}$ Ibn Hawqal, 118; translation in Kramers and Wiet (1964), 117.

${ }^{66}$ William of Apulia, Book III, lines 332-6, pp. 182-3.

${ }^{67}$ Ibn Hamdīs, BAS (Arabic), 651; translation in Amari, BAS, 234.

${ }^{68}$ Catana Sacra (1654), 85.
} 


\section{The Muslims of Sicily under Christian rule}

mosques at least into the 1180s. Ibn Jubayr recalled mosques in Termini, Qașr Sa ${ }^{c} d$ (Solento castle), Palermo, Alcamo and Trapani.

Somewhat counter-intuitively, the role of the church and the process of church building may have little bearing on the conversion question. As the examples of the 'palace Saracens' and some of the

Muslim elite show, conversion was more a political or social matter than a religious one. Indeed, the role of the Church was conspicuously absent in the examples we know of. Although at least fifty Latin monasteries had been founded by the end of the Norman period, their location was predominantly towards the east and northeastern parts of the island and were made partly according to existing supply and demand. As such, they were poorly placed to promote Christianity, prompting the fair conclusion that Latin monasteries 'were not intended as agents of Latinisation'. ${ }^{69}$

The example of Ibn Zur'a and his mosque conversion show how much of the spiritual welfare of Muslim religious communities may have been in the hands of private individuals. It also provides an insight behind the possible reasons for conversion of the Muslim social elite whose authority represented the keystone of indirect rule and who might have provided useful leverage in fostering wider conversions further down, the social scale. Throughout the Norman period, there are examples of similar types of conversions amongst the Muslim elite or community leaders and it seems to have been a continuing concern. We cannot be sure whether this pattern of constantly pruning back the already depleted Muslim leadership was also designed to cause a trickle-down conversion effect, but there is a clear hint that the policy had the potential to set in motion a wider trend. We are told by Ibn Jubayr that the Sicilian Muslim leader Abu l-Qāsim, who had enjoyed a long career in commerce and the fiscal administration, was under considerable pressure to convert but had refused. On his social standing in the 1180s, Ibn Jubayr reported that the Christians reckoned that if he had converted then every other Muslim on the island would have followed suit. ${ }^{70}$ But while there is evidence to suggest that figures among the higher social groups were deliberately and consistently earmarked for conversion, it is doubtful whether any conversion policy was, or could have been, applied directly very far down the social scale. At a district administrative level, there is little evidence that relates to officials' names and

\footnotetext{
${ }^{69}$ White (1938), 59-60.

${ }^{70}$ Ibn Jubayr, 315; translation in Broadhurst (1952), 360.
} 
religious persuasion, but at least some provincial governors ( ${ }^{c} \bar{a} m i l-\mathrm{s}$ or strategoti) are known or thought to have been Christians. ${ }^{71}$ However, at village level in the south-west, names of local village sheikhs, $q \bar{a} \underline{d} \bar{i}$-s ('magistrates'), $r a^{\top} \bar{\imath} s$-s ('heads'), $q \bar{a}^{\supset} i d-s$ ('leaders') and their families that appear on villein registers reveal only one individual who seems to have been a Christian. ${ }^{72}$ Yet this is not to deny that the lower social levels were unaware of the changes and pressures that had been increasingly brought to bear on those within the higher echelons of their own community or were unaffected by a number of powerful social undercurrents.

\section{Changes to the religious base: onomastic data as evidence}

Changes to the socio-religious base of the island cannot be traced with ease due to the lack of corroborative evidence. At the heart of the question is whether reported examples of conversion were illustrative and typical of wider change, or conversely, whether they were singular instances recorded precisely in virtue of their exceptional nature. In recent years, attempts have been made, with varying degrees of caution, to reconcile onomastic data with evidence for conversion or to show the existence of an independent ArabChristian community. ${ }^{73}$ Miscellaneous documents provide short lists of witnesses and signatories, but more importantly, a number of fiscal registers of villeins survive. These were compiled between 1095 and 1183, and recorded several thousand names of household heads whose families had been granted to landlords. In some cases, the villeins, the vast majority of whom seem to have been Muslim, were categorised according to place and/or religion and many of the names suggest professions, places of origin and social or religious background. Some names even comprise of elements derived from more than one language and are perhaps indicative of the somewhat mottled composition of Sicilian society.

Certainly this onomastic evidence offers tempting bait, but it provides insufficient information from which to reconstruct reliable models of religious conversion, socio-economic conditions or

\footnotetext{
${ }^{71}$ For example, George of Antioch and a certain Abū Țayyib, son of sheikh Stefan, are attested as strategoi of Iato in 1114 and 1149. See Cusa, Diplomi, 515 and 29. 265a.

${ }^{72}$ The Christian-sounding $q \bar{a}^{\supset} i d$ Yūsuf Qissīs or 'Joseph Priest'. Cusa, Diplomi,

${ }^{73}$ Johns (1995) and Bresc and Nef (1998).
} 
migration patterns due to the number of serious quantitative and qualitative reservations that inevitably surround this type of data. Nonetheless, the data does produce a number of thought-provoking examples. We find, for instance, a significant minority of individuals with intriguing combinations of names. Perhaps the most confused example comes from a Greek document of sale of 1169 involving a certain Christodoulos and Sitt al-Husūn and which concerned a house in Palermo. ${ }^{74}$ He was the son of an Abu l-Sayyid; she was the daughter of Peter of Castronuovo who signed his name in Latin, and husband of an ${ }^{\mathrm{c}} \mathrm{Abd}$ al-Sa ${ }^{c} \overline{1} \mathrm{~d} .{ }^{75}$ Among the other witnesses to the deal were Simeon, son of Andrea al-Raḥhām who signed in Arabic as well as a certain Theodore, the son of Leo al-Khanzārī (the Arabic for pig-farmer) who signed in Greek. It is important to add that although such a strange mix of names was not untypical for those involved in land or house sales around Palermo in the 1160s and 70s, it was not representative of the norm among the wider population of rural Muslim villeins. As we shall also see, it is weak to assume that Arabic names should be automatically associated with Muslims or non-Arabic names with converts.

The uncertainty surrounding the interpretation of mixed names is compounded by the peculiar and enduring tendency to adopt alternative names. An Arabic register from 1117 recorded a villein as 'Muhammad, who in Greek is called Bānzūl'. ${ }^{76}$ At the other end of the social scale, the 'palace Saracen' $q \bar{a}^{\supset} i d$ Peter was also known in Arabic by the Frankish name Baron. When he fled back to North Africa in 1167 to work for the Almohads, he took the name Ahmad al-Șiqillī ${ }^{77}$ There was a Sicilian Christian amīr Eugenios 'tou kalou' or literally 'of the good', also known by his Arabic cognate, Abū 1Tayyib, not to be confused with his namesake, the famous trilingual scholar and Master of the Duana Baronum on the mainland. ${ }^{78}$ Indeed, there are a number of names that may have been considered equivalents such as Christodoulos and ${ }^{\mathrm{c}} \mathrm{Abd}$ Allāh or ${ }^{\mathrm{c}} \mathrm{Abd}$ al-Masīh, although it is rare to find examples explicitly said to be equivalents. The names 'Christodoulos' and the feminine version of

\footnotetext{
${ }^{74}$ Cusa, Diplomi, 76.

${ }^{75}$ Peter of Castronuovo is possibly identical to the Master Captain of Apulia in the mid-1150s who had the same name, see Tyrants, 119.

${ }^{76}$ Guillou (1963), 55.

77 'Ahmad the Sicilian' see Johns and Metcalfe (1999), 231 n. 24.

${ }^{78}$ As recorded in a Latin translation of 1258 from a Greek-Arabic original of August 1175, cf. Spata (1862), 451-6. See Jamison (1957), 56-8 for the two amirs.
} 
'Christodoula' (literally 'the slave of Christ') are highly unusual as Greek names and are barely attested outside Sicily, yet were common on the island itself. The addition of 'doulos' seems to echo a translation of the Arabic ' $A b d$ al-for 'slave of', which is followed by a name or attribute of God in Muslim personal names. ${ }^{79}$

Some common names, adapted from Arabic, such as Bucheris, Maimunis, Mules, Morabito and Changemis were popular in communities where most people had names of Greek or mixed Arabic-Greek origin. ${ }^{80}$ This raises the likelihood that the many religiously neutral Arabic names used in Christian circles had long since ceased to be considered the preserve of Muslim communities. It is also quite probable that the people Latin sources called 'Greeks', in very many cases, can be considered as part of a wider sociolinguistic group that included many who might also be described as 'Arab-Christians'. Latin sources presumably referred to 'Greeks' as such, not only on confessional grounds and because Greek was the language of their liturgy, but also because, at least in the early days, Greek was the most obvious medium of communication (either directly or indirectly) between the Normans and the indigenous Sicilian Christians. However, it may be oversimplified to regard 'Greeks' and 'Arab-Christians' as two distinct communities because it is quite probable that many indigenous Sicilian Christian groups on the island comprised of bilingual Arabic-Greek speakers, the relative strengths of their languages and identities contingent on the greatlyvarying background cultures and circumstances of their particular region. Indeed, a large body of vernacular interferences between Greek and Arabic that appear regularly in both public and private documentation throughout the entire Norman period suggest a similar conclusion of widespread Greek-Arabic bilingualism. ${ }^{81}$

\footnotetext{
${ }^{79}$ In a Greek confirmation from 1117, Count Roger II was described as Christ's doulos, Cusa, Diplomi, 385.

${ }^{80}$ From the Arabic names Abū Bakr, Maymūn, Mawlā, Murābit and Hajjām. All are also modern Sicilian surnames, derived from the Greek form of the original Arabic i.e. Buccheri, Maimone, Mulè, Morabito and Cangemi, see Caracausi (1993). See also, the names in the villein communities around Patti and Nicótera, Garufi (1928), 92-100, and Cusa, Diplomi, 26-7.

${ }^{81}$ Metcalfe, Muslims and Christians in Norman Sicily. Arabic-speakers and the end of Islam, (2003). A specific example was the Arabic-speaking cleric whom Robert Guiscard sent as an envoy to Palermo in 1061. See Amatus, V.24, p. 244.
} 
The Muslims of Sicily under Christian rule

\section{Distinguishing between Muslims and Sicilian Christians}

In the villein registers that recorded largely rural Muslim communities, there are some names traceable to Greek and a few to Latin or Frankish origins. Overall, these names represent only a very small proportion of the total (less than three percent), and the more obvious conclusion that 97 percent of the villeins had names derived from Semitic or Arab-Islamic traditions should not be overlooked. However, Greek/Latin and Muslim names appear to have been common among the Christian community of Corleone in $1178 .{ }^{82}$ Over one third of these had names with non-Arabic or mixed elements. The names of the Corleone Christians are remarkable in three respects. First, the preference for Arabicised forms of Greek names e.g. Raqlī (Herakleios) and B.r.nqat (Pankratios) contributes positively to the suggestion that Christian families with Greek names were well assimilated into the background Arab-Islamic culture of western Sicily. Secondly, we see the same unpredictable mix of Greek and Arabic elements that were characteristic of some (nonvillein) Palermitan families. This suggests that the adoption of names with diverse origins was a conscious and considered practice within some communities. Among the Christian villeins from Corleone, we find a certain Makhūna who had a son Nikiforos, who in turn had sons called Khilfa and Abū Ghālib. Finally, several names more usually associated with Muslims can be found among this community too. These include two Muhammad-s, an ${ }^{\mathrm{c}} \mathrm{Abd}$ Allāh, Hammūd, Ahmad and an ${ }^{\mathrm{c}}$ Alī. Given the long history of ArabIslamic influence and assimilation in that area, combined with observations made about naming and identity, there is no reason to import the notion that these were converts to Christianity. ${ }^{83}$ Nonetheless, this evidence points to a conclusion with far-reaching implications. The Christian families from Corleone were listed beside their fellow Muslim villeins from the same area. But while the Muslims easily formed the majority, the Christians represented 19 percent of the total. Thus, as Jeremy Johns has pointed out, 'if Christian culture had survived amongst the Muslim peasantry of the

\footnotetext{
${ }^{82}$ Cusa, Diplomi, $145-7$. The names of 51 household heads and newly-weds were recorded.

${ }^{83}$ Kedar (1984), 51, 'it stands to reason that many of [these], all serfs of the abbey of Monreale, were converts to Christianity'.
} 
Val di Mazara where Arab settlement was heaviest, how much more must it have done so in the rest of the island? ${ }^{84}$

Apart from the Christians of Corleone (and, elsewhere, the Jews of Catania), it is generally presumed that all others who were not specifically listed as non-Muslims in the charters and villein registers were, in fact, Muslims. Yet this assumption presents difficulties because some names on the register suggest that Sicilian Christians were otherwise registered alongside Muslims. Among others, these included villeins called al-Rāhib ('the monk') ${ }^{85}$ al-Q.ljūrī (Greek kalogeros, 'the monk'), ${ }^{86}$ al-Qissīs ('the priest'), ${ }^{87} \mathrm{Abu}$ 1-Salīb ('of the cross'), ${ }^{88}$ al-Nastasī' (Greek anastasis, 'resurrection'), ${ }^{\dot{8} 9}$ and alMaranāwiyya ('the Maronite'). ${ }^{90}$ To clinch the case for the documents containing a mix of Muslims and Christians, there exists a Latin charter of 1136, which positively identifies eleven named villeins as Christian, and twenty four others as 'Saracens' (i.e. Muslims). ${ }^{91}$ When this list came to be re-issued as a confirmation in Arabic and Greek by the royal chancery nine years later, this religious information was omitted. ${ }^{92}$ So, at least in this case, the royally confirmed donation mixed Christians and Muslims together indiscriminately. One effect of this was that the registers would have been of no help to landlords had they wanted to use them to collect the jizya, so instead, they often resorted to drawing up their own lists based on the contents of the royal concession. ${ }^{93}$

The possibility that one could find Christians called Muhammad living besides Muslims with Greek names only compounds our inability to distinguish Sicilian Christians from Muslims. While this threatens to undermine socio-historical evaluations that have considered the villein communities in the west as exclusively Muslim or of others as simplistically 'Greek', it adds to our understanding of the cultural and linguistic proximity of many native

\footnotetext{
${ }^{84}$ Johns (1995), 152.

${ }^{85}$ Cusa, Diplomi, 148a, 148b, 151 a, 163 b.

${ }^{86}$ Ibid., 479a.

${ }^{87}$ Ibid., 163a, 265a, 266b.

${ }^{88}$ Ibid., $163 \mathrm{~b}$.

${ }^{89}$ Ibid., 578 a.

${ }^{90}$ Ibid., 169a.

${ }^{91}$ Documenti inediti, 25-6 no. 11.

${ }^{92}$ Cusa, Diplomi, 479.

${ }^{93}$ For the registers, translated into Latin, that recorded villeins of the churches of Lípari-Patti and Cefalù, see Garufi (1928), 92-100, Rollus Rubeus, 39-41.
} 


\section{The Muslims of Sicily under Christian rule}

Sicilian Christians to the Muslims. It is also clear that the complex and subtle dynamics of Sicily's unique socio-linguistic and religious communities bear only passing resemblance to those of Spain and share none of the terms used there, such as Morarabs, Marranos, Moriscos or Mudejars. ${ }^{94}$ Relatively small in number as Christians who knew Arabic in Sicily were, they had played a disproportionately important role in the administration and also in the social cement of the island. In effect, they acted as an important intermediary between the Muslims and Sicily's other religious communities in the sense that they shared connections with their Muslim and Jewish neighbours through use of the same language and many aspects of a shared cultural heritage. At the same time, all the island's Christians were linked in the sense that they shared a common bond of faith in its various forms.

If Muslims or Jews had wanted to convert or incline towards Christianity, it is clear that they would have faced some serious social obstacles. The 'Latin' communities, especially those of immigrant northern Italian 'Lombards', were the Muslims' principal enemy and relations between the two parties were often bitterly hostile. 'Falcandus' noted how a massacre of Muslims in Palermo in 1161 was followed by 'Lombard' disturbances on the other side of the island in Syracuse and Catania. Significantly, he recalled that some Muslims "secretly slipped away in flight or, assuming the guise of Christians, escaped to less dangerous Muslim towns in the southern parts of Sicily'. ${ }^{95}$ Under these circumstances, even the most determined would have found it hard to overcome the considerable social and political difficulties involved in conversion, let alone the significant language barrier. On the other hand, any Muslims who chose to re-align themselves with Arabic-speaking elements of Christian communities might have found a safer alternative solution.

The cultural proximity of Muslims and non-Latin Christians generally is shown in an extraordinary piece of eye-witness evidence. In Palermo around Christmas in 1184, young Christian women caught the eye of Ibn Jubayr as they passed by him on their way to the Byzantine Greek church of St. Mary of the Admiral, founded by George of Antioch in 1143. He vividly recalled that:

\footnotetext{
${ }^{94}$ For a more analogous view of Spain and Sicily, see Bresc (1980).

${ }^{95}$ Falcandus, 70; translation in Tyrants, 121-2.
} 


\section{Alex Metcalfe}

the Christian women's dress in this city [Palermo] is the dress of Muslims; they are eloquent speakers of Arabic (fașinhât al-alsan) and cover themselves with veils. They go out at this aforesaid festival [Christmas] clothed in golden silk, covered in shining wraps, colourful veils and with light gilded sandals. They appear at their churches bearing all the finery of Muslim women in their attire, henna and perfume. $^{96}$

Clearly, there were great similarities between some Arabic-speaking Christians and Muslim communities with regard to their culture, language and appearance. Churches, some of which used to be mosques and probably still looked like them, even performed a rite in Arabic. ${ }^{97}$ Certainly, when the need arose, Muslims in the west could convincingly pass for Sicilian Christians, as confirmed by 'Falcandus' when he described how Muslims fled for the safety of the south-west by pretending to be Christians. And if some Muslims were deliberately smudging the margins of their identity then, as we have seen, they had the high-ranking and dissembling precedents of the 'palace Saracens' and conspicuous members of the Muslim elite to emulate.

While the imbalance of the island's religious base was initially caused by Latin-Christian immigration and finalised by the suppression of the Muslim rebellions, it is also likely that the narrowing of the gap between the fringes of different socio-linguistic and religious groups had created something of a sliding social scale. In some parts of Sicily, divisions within this may never have been very distinct anyway. In turn, this contributed to the hazy transition from an Arab-Muslim culture to a Christian-based blend within two centuries with very little direct or explicit evidence for widespread conversion. So, rather than a straightforward picture of socio-religious change, a more complex and blurred spectrum of shifting identities and allegiances emerges as the margins of some Muslim communities merged indistinguishably with their Sicilian Christian neighbours who also knew Arabic, a move that further obfuscated the defining edges of such social groups and thereby allowed advantage to be taken of the protection this might offer. Within bilingual ArabicGreek Christian communities, the trend was back towards their old 'Greek' ways and names and ultimately towards the prestigious mores of the 'Latin' settlers. Thus, the number of people who knew Arabic and claimed to be Christian can only have swelled during the

${ }^{96}$ Ibn Jubayr, 307; translation in Broadhurst (1952), 349-50

${ }^{97}$ Johns (1995), 142-3. 


\section{The Muslims of Sicily under Christian rule}

second half of the twelfth century and, outside rebel strongholds, this number is likely to have deflated with some rapidity after the 1220s, as assuming the badge of Latinate manners and speech became a crucial measure of identity and an obvious way to avoid the increasingly stigmatic and perfidious association of Arabic and Islam.

\section{The end of the Muslims: rebellion and deportation}

But while twelfth-century Sicily witnessed the long-term erosion of boundaries between some socio-religious groups, Christian rule had also provoked a range of responses as shown by those among a 'fundamentalist' fringe whose attitudes could only have hardened over time. In Palermo, Ibn Jubayr recalled 'innumerable' mosques (masjid-s) in which teachers of the Quran kept themselves apart from their Muslim brethren who were under the protection (dhimma), and therefore the taxes, of Christian rule. Consequently, we are told, they had no security for themselves, their money, wives or children. ${ }^{98}$ It is not known how many Muslim community leaders had stepped outside the tax-for-protection mechanism, but those who did exposed themselves to great personal pressures and the threat of being stripped of their wealth with impunity. ${ }^{99}$

A stream of disaffected Muslims from the towns may have helped to politicise the south-western Val di Mazara, particularly after the pogroms of 1161, prior to which the Muslims (at least those in Palermo) had been disarmed. ${ }^{100}$ In the Val di Mazara, Muslim villeins who had lived and worked on crown land made up most of the population. With the vast royal concessions of this same land made between 1176 and 1185, they passed into the hands of the Latin church of S. Maria Nuova in Monreale. Little is known about the reasons behind this apparently most generous of grants or the subsequent relationship between the church and its villeins. However, those Muslims who had perhaps preferred to take their lead from

the unyielding examples of Abu 1-Qasim and the Quranic teachers of Palermo, rather than from the ambivalent taqiyya of the 'palace

\footnotetext{
${ }^{98}$ Ibn Jubayr, 305-6; translation in Broadhurst (1952), 349

${ }^{99}$ The poet Ibn Qalāqis, patronised by Abū l-Qāsim who was probably responsible for collection of the jizya on behalf of the fiscal administration and who was later deprived of much of his vast wealth, urged him to save the Muslims of Syracuse from the burden of their taxes, De Simone (1996), 90.

${ }^{100}$ Falcandus, 57; English translation, Tyrants, 110.
} 
Saracens' or other 'converts', rose in a revolt on the death of William II in 1189, aimed more at self-preservation than a bid for outright power. The rebels held out with a notable degree of independence on the former estates of Monreale under the leadership of a certain Ibn ${ }^{c}$ Abbād who even had coins minted in his name. ${ }^{101}$ However, from the 1220s, defeated groups of Muslim rebels were deported to the colony of Lucera on the Italian mainland, swiftly and effectively bringing about the demise of Islam in Sicily.

Finally, although no vestiges of specifically Islamic culture survive to this day, there remains evidence of Arabic influence principally in Sicilian toponymy. Arabic has also had a characteristic, but largely superficial, impact on the island's modern dialects. To a considerably more intangible degree, some see an authentic 'Oriental' flavour to local architecture, customs and cookery. ${ }^{102}$ More importantly, there exists a body of modern Italian surnames derived from Arabic, but hardly any recall specifically Islamic names. It is thus probable that these were passed down via the offspring of old Arab-Christian and Jewish families or perhaps from later Spanish immigrants. Thus, the Sicilian Muslims, weakened by civil war, military defeat and emigration in the eleventh century, then by the long-term effects of radical demographic, socioreligious and political change in the twelfth and finally by military defeat again in the thirteenth, could have represented only a miserable minority of the population by the 1220s. Following the rebels' failure and final deportations to Lucera in 1246, any remaining Muslims in Sicily were but an inconsequential force, leaving the western interior abandoned and depopulated. ${ }^{103}$

\section{BIBLIOGRAPHY AND ABBREVIATIONS}

Abulafia, D. (1977), The Two Italies. Economic Relations between the Norman Kingdom of Sicily and the Northern Communities, Cambridge.

Abulafia, D. (1990), 'The End of Muslim Sicily' in Muslims under Latin Rule 1100-1300, ed. J. M. Powell, Princeton, 103-133. Ahmad, A. (1990), A History of Islamic Sicily, Edinburgh.

\footnotetext{
${ }^{101}$ D’Angelo (1975), 149-53.

102 Bresc (1985), 245-6.

${ }^{103}$ Bresc (1986), 594-602, Abu1afia (1990), and Johns (1992), 407-20.
} 
Amari, $B A S=$ Biblioteca arabo-sicula (Italian translation), 2 vols. Turin, 1880.

Amari, M. (1933-39), Storia dei muslmani di Sicilia, 3 vols, ed. and revised by C. A. Nallino, Catania.

Amari, M. (1971), Le epigrafi arabiche di Sicilia, 2nd ed. revised by F. Gabrieli, Palermo.

Amatus = Storia de'Normanni de Amato di Montecassino, ed. V. de Barolomeis, (Fonti per la storia d'Italia), Rome, 1935.

$B A S($ Arabic $)=$ Amari, Biblioteca arabo-sicula (Arabic), 2 vols, revised by U. Rizzitano, Palermo, 1988

Borsook, E. (1990), Messages in Mosaic. The Royal Programmes of Norman Sicily 1130-87, Oxford.

Bresc, H. (1980), 'Mudéjars des pay de la couronee d'Aragon et sarrsins de la Sicile normande: le problème de l'acculturation' in $X$ Congresso de Historia de la Corona de Aragón: Jaime I y su epoca, Zaragoza, 51-60. Reprinted in Bresc (1990).

Bresc, H. (1985), 'La formazione del popolo siciliano' in Tre millenni di storia linguistica della Sicilia (Atti del convegno della Società italiana in Glottologia, Palermo, 1983), Pisa, 594-604. Reprinted in Bresc (1990).

Bresc, H. (1990) Politique et société en Sicile, XII ${ }^{e}-X I V^{e}$ siècles, Aldershot.

Bresc, H. and Nef, A. (1998), 'Les Mozarabes de Sicile (11001300)' in Cavalieri alla conquista del sud. Studi sill'Italia normanna in memoria di Léon-Robert Ménager, ed. J.-M. Martin and E. Cuozzo, Bari, 134-56.

Brett, M. (1995), 'Muslim justice under infidel rule' Cahiers de Tunisie, 38/155-61, 325-68. Reprinted in Brett (1999).

Brett, M. (1999), Ibn Khaldun and the Medieval Maghrib, Aldershot.

Broadhurst, R. (1952), The Travels of Ibn Jubayr, London, 1952.

Cahen, C. (1965), 'Djizya' and 'Dhimma' in Encyclopedia of Islam ( $2^{\text {nd }}$ edition), Leiden, II: 559-62 and 227-31.

Caracausi, G. (1993), Dizionario onomastico della Sicilia, 2 vols, Palermo.

Catana Sacra = Catana Sacra sive de episcopis Catanensibvs rebusque ab iis praeclare gestis a Christianae religionis exordio ad nostram usque aetatem, ed. G. B. De Grossis, Catania, 1654.

Colin, G. S., Duri 'A. and Gottschalk, H. L. (1962), 'Dīwān' in Encyclopedia of Islam (2 ${ }^{\text {nd }}$ edition), Leiden, II: 323-37. 
Cusa, Diplomi $=$ I diplomi greci ed arabi di Sicilia, ed. S. Cusa, Palermo, 1868-82 (Reprinted Cologne and Vienna, 1982).

D’Angelo, F. (1975), 'La monetazione di Muhammad ibn 'A Abbād emiro ribelle a Federico II di Sicilia' Studi magrebini 7, 149-53.

De Simone, A. (1996), Splendori e misteri di Sicilia in un'opera di Ibn Qalāqis, Messina.

De Simone, A. (1999), 'Alla corte di Ruggero II: tra poesia e politica' in A. De Simone, Nella Sicilia 'araba' tra storia e filologia, Palermo, 3-15.

Demus, O. (1950), The Mosaics of Norman Sicily, London.

Documenti inediti $=$ I documenti inediti dell'epoca normanna in Sicilia, ed. C. A. Garufi (Documenti per servire alla storia di Sicilia, Ser. I.xiii) Palermo, 1899.

Douglas, D. (1976), The Norman Fate, 1100-1154, London.

Falcandus = La Historia o Liber de Regno Sicilie e la Epistola ad Petrum Panormitane Ecclesia Thesaurium di Ugo Falcando, ed. G. B. Siragusa, (Fonti per la storia d'Italia), Rome, 1897.

Garufi, C. A. (1928), 'Censimento e catasto della populazione servile. Nuovi studi e richerche sull'ordimento amministrativo dei Normanni in Sicilia nei secoli XI e XII', Archivio storico siciliano 49, 1-100.

Guillou, A. (1963), 'Inchiesta sulla populazione greca della Sicilia e della Calabria nel medio evo', Rivista storico italiano, 1xxv.5368. (Reprinted in A. Guillou, Studies in Byzantine Italy, London, 1970).

Ibn Hawqal = Opus geographicum (Șürat al-arḍ), $2^{\text {nd }}$ edition, ed. J. H. Kramers, 2 vols, Leiden, 1938-9.

Ibn Jubayr = Riḥlat Ibn Jubayr (Arabic edition), Dār al-Șādir, Beirut, 1964.

Jamison, E. (1957), Admiral Eugenius of Sicily. His Life and Work and the Authorship of the Epistola ed Petrum and the Historia Hugonis Falcandi Siculi, London

Johns, J. (1983), The Muslims of Norman Sicily, c. 1060-c. 1194. D.Phil. dissertation (unpubl.), University of Oxford.

Johns, J. (1986), 'I titoli arabi dei sovrani normanni di Sicilia' Bollettino di Numismatica 6/7, 11-54

Johns, J. (1993), 'The Norman Kings of Sicily and the Fatimid Caliphate' in Chibnall, M. (ed.) Anglo-Norman Studies 15, Proceedings of the Battle Conference 1992, 133-59. 
Johns, J. (1995), 'The Greek Church and the conversion of Muslims in Norman Sicily' Byzantinische Forschungen 21, 133-57.

Johns, J. and Metcalfe, A. (1999), 'The Mystery at Chúrchuro: Conspiracy or Incompetence in Twelfth-Century Sicily?' Bulletin of the School of Oriental and African Studies 62, 226-59.

Kedar, B. (1984), Crusade and Mission. European Approaches towards the Muslims, Princeton.

Kitzinger, E. (1960), The Mosaics of Monreale, Palermo.

Kramers J. and Wiet G., (1964) Configuration de la terre (Șūrat alard), 2 vols, Beirut.

Malaterra $=$ De Rebus Gestis Rogerii Calabriae et Siciliae Comitis auctore Gaufredo Malaterra, ed. E. Pontieri, (Rerum Italicarum Scriptores, $2^{\text {nd }}$ series), Bologna, 1927.

Al-Maqrīż̄ $=$ Kitāb al-muqaffā al-kabìr ed. M. al-Ya' ${ }^{\mathrm{c}} \mathbf{a} w \overline{1}, 8$ vols, Beirut, 1991.

Marongiu, A. (1963), 'A Model State in the Middle Ages. The Norman Swabian Kingdom of Sicily', Comparative Studies in Society and History 6, 307-20.

Matthew, D. (1981), 'The Chronicle of Romuald of Salerno' in The Writing of History in the Middle Ages. Essays presented to Richard William Southern, ed. R. H. C. Davies and J. M. Wallace-Hadrill, Oxford, 239-74.

Maurici, F. (1999), Breve storia degli arabi in Sicilia, Palermo.

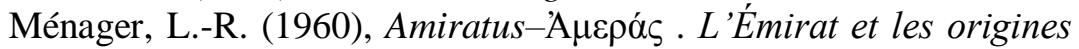
de l'amirauté (XI-XIII siècles), Paris.

Metcalfe, A. (2003), Muslims and Christians in Norman Sicily. Arabic-speakers and the end of Islam, London and New York.

Peter of Blois = Epistolae, in Patrologia Latina, 221 vols, ed. J. P. Migne, Paris, 1844-64, ccvii.1-560.

Roger II Diplomata $=$ Rogerii II Regis Diplomata Latina, ed. C.-R. Brühl (Codex Diplomaticus Regni Siciliae, Ser. I.ii(1)), Cologne, 1987.

Rollus Rubeus $=$ Privilegia ecclesie Cephaleditane a diversis regibus et imperatoribus concessa recollecta et in hoc volumine scripta, ed. C. Mirto, (Documenti per servire alla storia di Sicilia, ser. 1, vol. 29), Palermo, 1972.

Romuald $=$ Romualdi Salernitani Chronicon, ed. C. A. Garufi (Rerum Italicarum Scriptores, $2^{\text {nd }}$ series), Città di Castello, 1935.

Southern, R. W. (1962), The Life of Saint Anselm, Archbishop of Canterbury, by Eadmer, London. 


\section{Alex Metcalfe}

Spata $=$ Le pergamene greche esistenti nel Grande Archivio di Palermo, ed. G. Spata, Palermo, 1862.

Strothmann, R. and Djebli, M. (2000), 'Takiyya' in Encyclopedia of Islam ( $2^{\text {nd }}$ edition), Leiden, 10: 134-6

Tronzo, W. (1997), The Cultures of His Kingdom. Roger II and the Cappella Palatina in Palermo, Princeton.

Tyrants $=$ The History of the Tyrants of Sicily by 'Hugo Falcandus' 1154-69, trans. G. A. Loud and T. E. J. Wiedemann, Manchester, 1998.

White, L. (1938), Latin Monasticism in Norman Sicily, Cambridge, Mass.

William of Apulia $=$ Guillaume de Pouille. La Geste de Robert Guiscard, ed. M. Mathieu, Palermo, 1861.

\section{ADDENDA (August 2009)}

Since the publication of this article in 2002, there have been a number of articles, conference proceedings and monograph studies relating to the Muslims of Norman Italy, in which updated and extensive bibliographies can be found. These include:

Andaloro, M. ed. (2006), Nobiles Officinae: perle, filigrane e trame di seta dal Palazzo Reale di Palermo, 2 vols, Catania.

Grube, E. and Johns, J. (2005), The Painted Ceilings of the Cappella: Islamic Art, Supplement I, Genova and New York.

Johns, J. (2002), Arabic Administration in Norman Sicily. The Royal Dīwān, Cambridge.

Johns, J. (2007), 'Arabic Sources for Sicily' in Byzantines and Crusaders in Non-Greek Sources 1025-1204, ed. Mary Whitby, Oxford.

Metcalfe, A. (2009), The Muslims of Medieval Italy, Edinburgh.

Molinari, A. and Nef, A. (2004), La Sicile à l'époque islamique: Questions de méthodes et renouvellment récent des problématique. Mélanges de l'École française de Rome. Moyen Âge 116/1, Rome.

Museum with No Frontiers (no author) (2004) Siculo-Norman Art: Islamic Culture in Medieval Sicily, Vienna.

Rapoport, Y. and Savage-Smith, E. (2007), The Book of Curiosities: A critical edition. (www.bodley.ox.ac.uk/bookofcuriosities). 